\title{
KOHORT EVALUASI CONTAINER INDEX (CI) SETELAH PELAKSANAAN FOGGING FOKUS DI DESA SIDAMULIH KECAMATAN RAWALO KABUPATEN BANYUMAS TAHUN 2016
}

\author{
Windy Diyah Atrikni*, Aris Santjaka, **, Arif Widiyanto, *** \\ Jurusan Kesehatan Lingkungan, Politeknik Kesehatan Kemenkes Semarang, \\ Jl.Raya Baturaden KM 12 Purwokerto, Indonesia
}

\begin{abstract}
Abstrak
Latar Belakang di Desa Sidamulih terdapat 2 kasus DBD serta tambahan 12 kasus penderita panas dalam 3 minggu. Maka, Dinas Kesehatan Kabupaten Banyumas melakukan fogging. Fogging fokus dilakukan dua kali. Tujuan penelitian mengetahui kondisi CI setelah fogging fokus sebagai parameter tidak langsung. Jenis penelitian observasional dengan pendekatan kohort. Pengambilan sampel menggunakan total sampling berjumlah 34 rumah. Hasil penelitian dianalisis menggunakan uji anova one way, hasil uji lanjut LSD ada beda CI sebelum fogging fokus pertama dengan 3 hari setelah fogging fokus pertama dan kedua, setelah 10 fogging fokus kedua nilai CI secara statistik sama dengan sebelum fogging fokus pertama, dan 17 hari setelah fogging fokus kedua terjadi penurunan CI secara drastis karena adanya PSN. Disimpulkan fogging fokus hanya efektif untuk menurunkan CI selama 10 hari dan PSN lebih efektif untuk menekan CI. Saran pemberantasan sarang nyamuk secara berkala.
\end{abstract}

Kata Kunci : Container Index, fogging fokus

\begin{abstract}
Abstrack
[Cohort Evaluation Container Index (CI) After Fogging Implementation Focused In Sidamulih Village Rawalo Subdistrict Banyumas Regency Year 2016]. Background: in Sidamulih village there are two cases of dengue and 12 cases of patients with the addition of heat within in 3 weeks. Thus, Banyumas District Health Office conducting fogging. Fogging focus done twice. This research was aimed to know the condition of CI after fogging focus as indirect parameter. This research design was observational with cohort approach. The sample using total sampling method amounted to 34 homes. The research results were analyzed using anova one way test, further test results LSD different before fogging focus with 3 days after the first and second fogging focus, after 10 days second fogging focus CI value were statiscally same before the first fogging focus, and after 17 days second fogging focus CI decreased drastically for their mosquito eradication activities. It is concluded that fogging focus only effective to reduce larvae density until 10 days after the second fogging focus and mosquito eradication is more effective to suppressing CI. So, Mosquito eradication should be done regularly.
\end{abstract}

Keywords: Container Index, fogging focus

\section{PENDAhuluaN}

Demam Berdarah Dengue (DBD) merupakan penyakit menular yang ditandai dengan panas tinggi mendadak tanpa sebab yang jelas disertai bintikbintik merah pada kulit. DBD disebabkan oleh virus dengue yang ditularkan ke manusia melalui gigitan

*) windydiyah70@gmail.com

**) arissantjaka@gmail.com

nyamuk Aedes aegepty (Kemenkes RI, 2011). Sejak tahun 1968 hingga tahun 2009, World Health Organization (WHO) mencatat Indonesia sebagai 
negara dengan kasus DBD tertinggi di Asia Tenggara. (Depkes RI, 2010.

Kejadian DBD masih ditemukan hingga saat ini, salah satu penyebabnya adalah kegiatan pemberantasan vektor DBD yang kurang maksimal. Pemberantasan vektor DBD yang tidak dilakukan sesuai anjuran seperti pemerikasaan jentik berkala, fogging serta PSN menjadi faktor penyebab masih ditemukannya DBD, menurut penelitian Sri Wahyuni (Tahun 2013) menunjukkan cakupan ABJ > 95\%, masih tetap ada kemungkinan timbulnya tempat perkembangbiakan jentik Aedes aegypti.

Di Desa Sidamulih Kecamatan Rawalo Kabupaten Banyumas terdapat 2 kasus DBD serta adanya tambahan 12 kasus penderita panas dalam periode 3 minggu, seperti yang dinyatakan dalam laporan Puskesmas Rawalo tanggal 25 November 2015. Maka, Dinas Kesehatan Kabupaten Banyumas melakukan intervensi berupa kegiatan $3 \mathrm{M}$ (Menutup, Menguras, Mengubur) dan fogging guna memutus mata rantai penularan DBD oleh nyamuk.

Fogging merupakan upaya paling sering dilakukan guna mempercepat penurunan densitas vektor Aedes $s p$ dengan harapan supaya angka kejadian DBD dapat ditekan dalam waktu yang cepat. Sedangkan Fogging fokus merupakan pemberantasan nyamuk DBD dengan cara pengasapan terfokus pada daerah tempat ditemukannya tersangka atau penderita DBD. Fakta lapangan justru menunjukkan adanya persistensi atau menetapnya endemisitas penyakit ini.

Fogging fokus secara teoritis dilakukan dua kali, fogging pertama dilakukan untuk membunuh nyamuk dewasa, fogging kedua dilaksanakan 7 hari setelah fogging pertama. Hal ini dimaksudkan agar jentik-jentik nyamuk sebelum fogging pertama sudah menjadi nyamuk dewasa maka, setelah 7 hari jentikjentik tersebut telah menjadi nyamuk dewasa karna siklus perkembangbiakan dari jentik ke nyamuk dewasa adalah kurang lebih 7 hari. Dengan demikian setelah fogging kedua tidak ada lagi nyamuk dewasa yang bertelur dan menjadi jentik. Penjelasan ini mengisyaratkan adanya dua hal indikator Fogging Fokus yaitu indikator langsung berupa penurunan densitas nyamuk dewasa dan indikator tidak langsung berupa penurunan densitas larva di desa Sidamulih Kecamatan Rawalo Kabupaten Banyumas.

Evaluasi efektifitas fogging fokus belum pernah ada dilakukan oleh Dinas Kesehatan dan jajarannya sampai sekarang, karena seringkali fogging yang dilakukan ada kepentingan politis atau hanya mengalihkan psycologi kekalutan masyarakat, dengan demikian peneliti ingin mengetahui beberapa hal yaitu apakah sudah terpenuhinya kriteria fogging fokus, apakah cara fogging fokus sudah sesuai dengan ketentuan yang ada.

Tujuan dalam penelitian ini yaitu untuk mengetahui Kondisi Container Index (CI) Setelah Pelaksanaan Fogging Fokus di Desa Sidamulih Kecamatan Rawalo Kabupaten Banyumas.

\section{BAHAN DAN METODE}

Variabel independen dalam penelitian ini yaitu fogging fokus dan variabel dependen yaitu CI, HI, BI, dan ABJ. Jenis penelitian ini adalah observasional dengan pendekatan kohort. Kohort yang dimaksud yaitu mengikuti pergerakan densitas larva dari sebelum dilakukan fogging fokus pertama sampai densitas larva setelah fogging fokus kedua mendekati densitas larva sebelum fogging fokus pertama. Pengambilan sampel menggunakan metode total sampling yaitu seluruh rumah di Desa Sidamulih yang menjadi target fogging fokus dalam radius 200 meter dari rumah 2 penderita dan bersedia untuk menjadi responden dalam penelitian ini yang berjumlah 34 rumah. Data diperloleh dengan cara observasi, wawancara, dan dokumentasi. Instrument yang digunakan berupa checklist, kuisioner, lux meter, thermohigrometer, anemometer. Pengolahan data yang digunakan uji anova one way.

\section{HASIL DAN PEMBAHASAN}

Penelitian ini dilakukan dengan cara memeriksa semua Container baik yang positif jentik maupun tidak kemudian dihitung nilai Container Index (CI), House Index (HI), Breteu Index (BI), Angka Bebas Jentik (ABJ) serta dilakukan pengukuran intensitas cahaya, suhu, dan kelembaban. Pengamatan tersebut dilakukan selama 5 kali yaitu sehari sebelum dilakukan fogging pertama, 3 hari setelah dilakukan fogging pertama, 3 hari setelah fogging kedua, 10 hari setelah fogging kedua, dan 17 hari setelah fogging kedua, sedangkan pengukuran kecepatan angin dilakukan 2 kali yaitu saat fogging fokus pertama dan kedua. 
1. Pengukuran Intensitas Cahaya

Pengukuran dilakukan pada pukul 07.00$10.00 \mathrm{WIB}$, adapun tempat yang ukur yaitu ruang tamu, kamar, kamar mandi, dan dapur dengan menggunakan alat lux meter. Intensitas cahaya selama penelitian cenderung naik turun dari 1 hari sebelum fogging fokus pertama sampai 17 hari setelah fogging fokus kedua. Rata-rata hasil pengukuran intensitas cahaya tertinggi pada ruang tamu responden 93,2 lux, kamar tidur 77 lux, kamar mandi 190,27 lux, dan dapur 94,79 lux. Tempat hinggap yang disenangi nyamuk setelah menghisap darah biasanya adalah tempat yang gelap dan lembab menurut Depkes RI Ditjen PP \& PL (2007).

2. Pengukuran Suhu

Pengukuran suhu dilakukan pada pukul 07.00-10.00 WIB disetiap rumah responden. Pengukuran suhu udara menggunakan alat thermohygrometer. Suhu di dalam rumah responden berkisar antara $25^{\circ} \mathrm{C}-32^{\circ} \mathrm{C}$. Suhu udara rata-rata tertinggi saat penelitian berlangsung adalah $29,56{ }^{\circ} \mathrm{C}$. suhu udara selama penelitian cenderung naik turun hal ini dikarenakan waktu pengukuran yang berbeda, dan keadaan cuaca saat pengukuran.

Nyamuk termasuk binatang berdarah dengan dan karenanya proses-proses metabolisme dan siklus kehidupannya tergantung pada suhu lingkungan, sehingga pengaturan suhu tubuh sangat tergantung pada lingkungannya. Pada suhu kurang dari $16^{\circ} \mathrm{C}$ dan lebih tinggi dari $32^{\circ} \mathrm{C}$

nyamuk akan mengalami gangguan petumbuhannya, suhu optimum pertumbuhan $25^{\circ} \mathrm{C}-27^{\circ} \mathrm{C}$. perubahan suhu sangat berpengaruh nyamuk, secara umum perubahan antara $5^{\circ}-6^{\circ} \mathrm{C}$ nyamuk tidak tahan hidup dan akan mengalami kesulitan beradaptasi. (Saputro Eko,2010 dalam Aris Santjaka,2013)

3. Pengukuran Kelembaban

Pengukuran kelembaban dilakukan pukul 07.00-10.00 WIB dengan menggunakan thermohygrometer. Kelembaban di rumah responden selama penelitian berkisar antara $60 \%$ $93 \%$. Nilai rata-rata kelembaban tertinggi selama penelitian berlangsung adalah $88,94 \%$.
Kebutuhan kelembaban yang tinggi mempengaruhi nyamuk untuk mencari tempat yang lembab dan basah sebagai tempat hinggap atau istirahat. Pada kelembaban kurang dari $60 \%$ umur nyamuk menjadi pendek (Depkes RI Ditjen PP \& PL, 2007).

Hasil pengukuran kelembaban di rumah responden menunjukkan bahwa rata-rata kelembaban selama penelitian berlangsung adalah $85,41 \%$. Hasil tersebut cocok untuk perkembangan nyamuk. Pengukuran kelembaban dilakukan di ruang keluarga rumah responden. Pada kelembaban tinggi nyamuk menjadi lebih aktif dan lebih sering menggigit sehingga akan mempercepat proses perkembangbiakan nyamuk.

\section{Pengukuran Kecepatan Angin}

Pengukuran kecepatan angin dilakukan saat fogging fokus pertama dan fogging fokus kedua dengan menggunakan anemometer. Hasil rata-rata pengukuran kecepatan angin saat fogging fokus pertama adalah $0,36 \mathrm{~m} / \mathrm{s}$, sedangkan saat fogging fokus kedua adalah $4,36 \mathrm{~m} / \mathrm{s}$.

Angin berpengaruh terhadap nyamuk pada beberapa aspek yaitu jarak terbang nyamuk, evaporasi cairan dalam tubuh nyamuk, dan suhu udara. Kecepatan angin 11-14 meter per detik atau 25-31 mill per jam akan menghambat penerbangan nyamuk. (Depkes RI,2007). Angin diperlukan untuk membawa asap masuk kedalam celah-celah bangunan, namun jika terlalu kencang maka asap akan cepat hilang terbawa angin.

\section{Deskripsi Pelaksanaan Fogging}

Konsentrasi insektisida yang digunakan saat fogging sudah sesuai dengan yang tertera pada label pestisida yang digunakan yaitu 0,5 per 10 liter solar. Konsentasi bahan yang digunakan harus mengacu pada label, karena bila dosis yang digunakan tidak tepat akan menimbulkan kerugian, tidak hanya dari segi biaya dan efikasi pengendalian tetapi juga berpengaruh terhadap keamanan manusia itu sendiri serta lingkungannya (magallona, 1980). Jenis insektisida yang digunakan untuk fogging yaitu dengan bahan aktif sipermetrin dari golongan peritroid.

Fogging dilakukan 2 siklus dengan interval waktu kurang dari 7 hari, menurut Dirjen Pengendalian Penyakit Menular fogging fokus 
dilakukan dengan frekuensi 2 siklus dalam interval 7 hari. Pelaksanaan pagi jam 06.00-10.00 atau sore jam 15.00-18.00, sedangkan waktu pelaksanaan fogging pertama tidak sesuai karena dilakukan pada pukul 11.00 WIB. Saat-saat pelaksanaan ini adalah berdasarkan pertimbangan kecepatan angin dan suhu udara pada saat tersebut pada umumnya rendah. Pengasapan diluar ruangan pada waktu tengah hari atau pada suhu tinggi akan sia-sia karena asap akan menyebar keatas, bukan kesamping sehingga pengasapan tidak maksimal. Oleh sebab itu fogging sebaiknya dilakukan pada pagi hari atau sore hari.

Fogging di dalam rumah dimulai dari ruangan yang paling belakang, jendela dan pintu ditutup kecuali pintu depan untuk keluar masuk petugas, fogging di luar rumah tidak dilakukan secara menyeluruh hanya sebagian kecil saja yang di fogging yaitu pada lingkungan teras rumah sedangkan untuk halaman samping dan belakang rumah tidak di fogging. Selama fogging dilakukan, penghuni rumah berada di luar.

6. Container Index (CI)

Container yang diperiksa pada penelitian ini beberapa diantaranya adalah bak mandi, tempayan, kaleng bekas, ban bekas, alamiah, sumur, pot bunga, dan lain lainnya. Nilai container Index $(\mathrm{CI})$ dapat digunakan sebagai alat pembanding yang penting dalam mengevaluasi program pengendalian vektor.

Tabel 1 : Hasil Perhitungan Container Index (CI)

\begin{tabular}{|c|c|c|c|c|}
\hline \multirow[b]{2}{*}{ Waktu Pemeriksaan } & \multicolumn{3}{|c|}{ Container Yang Diperiksa } & \multirow[b]{2}{*}{ Kategori pembacaan } \\
\hline & Jumlah & Positif & $\%$ & \\
\hline $\begin{array}{lrr}1 & \text { hari } & \text { sebelum } \\
\text { fogging } & \text { fokus } \\
\text { pertama } & \\
\end{array}$ & 110 & 15 & 13,63 & Risiko Tinggi \\
\hline $\begin{array}{l}3 \text { hari } \\
\text { fogging } \\
\text { pertama }\end{array}$ & 85 & 2 & 2,31 & Risiko Rendah \\
\hline $\begin{array}{lr}3 \quad \text { hari } & \text { setelah } \\
\text { fogging } & \text { fokus } \\
\text { kedua } & \end{array}$ & 51 & 3 & 5,8 & Risiko Rendah \\
\hline $\begin{array}{l}10 \text { hari setelah } \\
\text { fogging fokus kedua }\end{array}$ & 49 & 13 & 26,53 & Risiko Tinggi \\
\hline $\begin{array}{l}17 \text { hari setelah } \\
\text { fogging fokus kedua }\end{array}$ & 56 & 1 & 1,78 & Risiko Rendah \\
\hline
\end{tabular}

Jika dilihat dari sisi persentase ada kecenderungan menurunnya nilai Container Index setelah kegiatan penyemprotan, tetapi naik drastis 10 hari setelah fogging fokus dan mengalami penurunan lagi pada 17 hari setelah fogging fokus kedua.

10 hari setelah dilakukan fogging fokus kedua persentase CI $26,53 \%$, kondisi ini sangat jauh berbeda dari pengamatan sebelumnya bahkan meningkat drastis. Hal ini dikarenakan pada saat dilakukan fogging fokus yang kedua masih ada nyamuk dewasa yang bertelur dan menjadi jentik, sehingga setelah 10 hari dilakukan fogging kedua telur dari nyamuk dewasa yg tidak mati sudah menjadi jentik karena siklus perkembangbiakan dari telur menjadi jentik sekitar 8-10 hari.

Telur nyamuk akan menetas dalam waktu \pm 2 hari setelah telur terendam air dan stadium jentik biasanya berlangsung antara 6-8 hari kemudian 
jentik menjadi pupa, menurut Servis MW, 1996;1-8 dalam Ayu Yulistyawati; 2011.

17 setelah fogging fokus kedua $\mathrm{CI}=1,78$ persen. Kondisi ini jauh berbeda jika dibandingkan dengan kondisi 10 hari setelah fogging kedua. Hal ini dikarenakan sehari sebelum dilakukan pengamatan, di Desa Sidamulih telah dilakukan Pemberantasan Sarang Nyamuk (PSN). PSN DBD merupakan bagian dari upaya mewujudkan kebersihan lingkungan, serta perilaku sehat dalam rangka mencapai masyarakat dan keluarga sejahtera. (Dirjen PPM dan PLP, 1992, h.3), oleh karena itu bisa dikatakan bahwa PSN memberikan efek lebih besar jika dibandingkan dengan fogging fokus yang telah dilakukan, jadi sebaiknya PSN dilakukan secara berkala untuk menurunkan densitas larva.

\section{House Index (HI)}

Nilai HI menggambarkan banyaknya rumah yang positif jentik dibandingkan dengan seluruh rumah yang diperiksa. Adapun hasil survey jentik pada rumah yang diperiksa dapat dilihat dalam tabel sebagai berikut :

Tabel 2 : Hasil Perhitungan House Index (HI)

\begin{tabular}{|c|c|c|c|c|}
\hline \multirow[b]{2}{*}{ Waktu Pemeriksaan } & \multicolumn{3}{|c|}{ Rumah Yang Diperiksa } & \multirow[b]{2}{*}{ Kategori pembacaan } \\
\hline & $\begin{array}{l}\text { Jumlah } \\
\text { Rumah }\end{array}$ & $\begin{array}{l}\text { Positif } \\
\text { jentik }\end{array}$ & $\%$ & \\
\hline $\begin{array}{lr}1 \quad \text { hari } & \text { sebelum } \\
\text { fogging } & \text { fokus } \\
\text { pertama } & \end{array}$ & 34 & 11 & 32,35 & Risiko Tinggi \\
\hline $\begin{array}{l}3 \text { hari } \\
\text { fogging } \\
\text { pertama }\end{array}$ & 34 & 2 & 5,88 & Risiko Rendah \\
\hline $\begin{array}{l}3 \text { hari } \\
\text { fogging } \\
\text { kedua }\end{array}$ & 34 & 3 & 8,82 & Risiko Rendah \\
\hline $\begin{array}{l}10 \text { hari setelah } \\
\text { fogging fokus kedua }\end{array}$ & 34 & 11 & 32,35 & Risiko Tinggi \\
\hline $\begin{array}{l}17 \text { hari setelah } \\
\text { fogging fokus kedua }\end{array}$ & 34 & 1 & 2,94 & Risiko Rendah \\
\hline
\end{tabular}

HI cenderung mengalami penurunan dari 1 hari sebelum fogging fokus pertama sampai 3 hari setelah fogging fokus kedua, meningkat lagi pada 10 hari setelah fogging fokus dan pada 17 hari setelah fogging fokus mengalami penurunan lagi karena ada nya kegiatan Pemberantasan Sarang Nyamuk (PSN) di Desa Sidamulih.

Nilai House Index yang lebih tinggi dari 10\% berarti menunjukkan daerah tersebut memiliki risiko yang tinggi terjadinya penularan Demam Berdarah Dengue (DBD). Rumah-rumah penduduk banyak ditemukan adanya jentik nyamuk yang dikhawatirkan akan menularkan penyakit DBD dari satu orang ke orang lainnya. Nyamuk Aedes aegypti mempunyai kebiasaan menggigit berulang-ulang (multibiters) bisa pada orang yang sama ataupun pada orang yang berbeda, sehingga transfer penyakit ini dapat terjadi dengan cepat. Penularan penyakit DBD juga tidak hanya selalu terjadi di ruang lingkup rumah seseorang tapi bisa saja berasal dari tempat yang lain. Misalnya di rumah tidak terdapat nyamuk Aedes aegypti, tetapi ketika berkunjung ke tetangga yang kebetulan rumahnya terdapat nyamuk aedes aegypti dan terjadi gigitan nyamuk yang mengandung virus dengue maka penularan penyakit DBD dapat terjadi di sana. (Tri Wahyuni Sukesi, 2012). 


\section{Breteau Index (BI)}

Nilai BI menggambarkan banyaknya tempat penampungan air yang positif jentik dibandingkan dengan seluruh rumah yang diperiksa. Adapun hasil survey jentik pada rumah yang diperiksa dapat dilihat dalam tabel 3 .

Jika dilihat dari sisi persentase ada kecenderungan menurunnya nilai Breteau Index setelah kegiatan penyemprotan, tetapi naik drastis 10 hari setelah fogging fokus dan mengalami penurunan lagi pada 17 hari setelah fogging fokus kedua.

Hasil penelitian ini meskipun tidak menunjukkan persentase yang mendekati 100 persen tetapi harus tetap menjadi perhatian karena meskipun tidak banyak tidak menutup kemungkinan nyamuk-nyamuk tersebut mampu menularkan penyakit DBD (Tri Wahyuni Sukesi, 2012).

Tabel 3 : Hasil Perhitungan Breteau Index (BI).

\begin{tabular}{lcccc}
\hline & \multicolumn{3}{c}{ Breteu Index (BI) } & \\
\cline { 2 - 3 } Waktu Pemeriksaan & $\begin{array}{c}\text { Jumlah } \\
\text { Rumah }\end{array}$ & $\begin{array}{c}\text { Container } \\
\text { Positif Larva }\end{array}$ & Kategori pembacaan \\
\hline $\begin{array}{l}\text { 1 hari sebelum } \\
\text { fogging fokus } \\
\text { pertama }\end{array}$ & 34 & 15 & 44,11 & Risiko Rendah \\
$\begin{array}{l}3 \text { hari setelah } \\
\text { fogging fokus } \\
\text { pertama }\end{array}$ & 34 & 2 & 5,88 & Risiko Rendah \\
$\begin{array}{l}3 \text { hari setelah } \\
\text { fogging fokus } \\
\text { kedua }\end{array}$ & 34 & 3 & & \\
$\begin{array}{l}10 \text { hari setelah } \\
\text { fogging fokus kedua }\end{array}$ & 34 & & & Risiko Rendah \\
$\begin{array}{l}17 \text { hari setelah } \\
\text { fogging fokus kedua }\end{array}$ & 34 & 13 & 38,23 & Risiko Rendah \\
\hline
\end{tabular}

Secara keseluruhan daerah Desa Sidamulih memiliki karakteristik daerah yang padat penduduk. Hal ini akan memberikan peluang yang makin besar untuk terjadinya penularan DBD. Kebiasaan menampung air pada bak mandi tanpa dibersihkan secara berkala misalnya, akan memberikan tempat perindukan bagi nyamuk Aedes aegypti, oleh karena itu sebaiknya masyarakat selalu membersihkan bak mandi secara berkala minimal satu kali dalam seminggu.

\section{Angka Bebas Jentik (ABJ)}

Keberadaan jentik di suatu wilayah diketahui dengan indikator Angka Bebas Jentik (ABJ). Hasil Angka Bebas Jentik didapatkan dengan menghitung jumlah rumah yang negatif jentik dibagi dengan jumlah rumah yang diperiksa. ABJ tinggi menunjukkan bahwa kebersihan lingkungan sudah baik, sehingga risiko terjadinya penyakit DBD akan berkurang. Adapun hasil survey jentik pada rumah yang diperiksa dapat dilihat dalam tabel 4.

Jika dilihat dari sisi persentase ada kecenderungan meningkatnya nilai angka bebas jentik setelah kegiatan penyemprotan, tetapi turun drastis 10 hari setelah fogging fokus dan mengalami peningkatan lagi pada 17 hari setelah fogging fokus kedua. 
Tabel 4 : Hasil Perhitungan Angka Bebas Jentik (ABJ)

\begin{tabular}{lcccc}
\hline \multirow{2}{*}{ Waktu Pemeriksaan } & \multicolumn{3}{c}{ Angka Bebas Jentik } & Kategori pembacaan \\
\cline { 2 - 4 } & $\begin{array}{c}\text { Jumlah } \\
\text { Rumah }\end{array}$ & $\begin{array}{c}\text { Negatif } \\
\text { Larva }\end{array}$ & $\%$ & Risiko Tinggi \\
\hline $\begin{array}{l}1 \text { hari sebelum } \\
\text { fogging fokus } \\
\text { pertama }\end{array}$ & 34 & 23 & 67,64 & \\
$\begin{array}{l}3 \text { hari setelah } \\
\text { fogging fokus } \\
\text { pertama }\end{array}$ & 34 & 32 & 94,11 & Risiko Tinggi \\
$\begin{array}{l}3 \text { hari setelah } \\
\text { fogging fokus } \\
\text { kedua }\end{array}$ & 34 & 31 & 91,17 & Risiko Tinggi \\
$\begin{array}{l}10 \text { hari setelah } \\
\text { fogging fokus kedua }\end{array}$ & 34 & 23 & 67,64 & Risiko Tinggi \\
$\begin{array}{l}\text { 17 hari setelah } \\
\text { fogging fokus kedua }\end{array}$ & 34 & 33 & 97,05 & Risiko Rendah \\
\hline
\end{tabular}

Masih rendahnya Angka Bebas Jentik di Desa Sidamulih jika dibandingkan dengan indikator nasional yaitu sebesar 95\% merupakan hal yang sangat perlu diwaspadai, hal ini dikarenakan rendahnya $\mathrm{ABJ}$ memungkinkan banyak peluang untuk proses transmisi virus (Hasyimi et.al, 2005 dalam Sunaryo dan Nova Pramestuti, 2012). Angka Bebas Jentik yang rendah dipengaruhi oleh beberapa faktor. Perilaku penduduk dalam hal menampung air untuk keperluan sehari-hari tidak hanya pada satu tempat dan jarang membersihkan bak penampungan air memungkinkan nyamuk Aedes aegypti memiliki peluang lebih banyak untuk bertelur (Sitorus dan Ambarita, 2004).

10. Uji Statistik

Data yang diperoleh dari pengamatan kemudian dianalisis menggunakan Uji Anova One Way untuk mengetahui perbedaan densitas larva pada sebelum fogging pertama, 3 hari setalah fogging pertama, 3 hari fogging kedua, 10 hari setelah fogging kedua, dan 17 hari setelah fogging fokus kedua. Hasil uji tersebut didapatkan hasil Nilai p (sig) $0,000<0,05$ berarti Ho ditolak artinya ada perbedaan antara densitas larva sebelum dan setelah dilakukan fogging fokus. Karena Ho di tolak maka uji lanjut LSD diteruskan, hasilnya ada beda sebelum fogging fokus dengan 3 hari setelah fogging fokus pertama dan kedua, 10 hari setelah fogging fokus kedua tidak ada beda, dan setelah 17 hari fogging fokus terjadi penurunan CI secara drastis karena adanya PSN, dengan demikian fogging fokus hanya efektif untuk menekan densitas larva sampai hari ke 10.

a. Sebelum Fogging fokus pertama dengan 3 hari Setelah Fogging fokus pertama.

Hasil analisis statistik antara sebelum fogging fokus pertama dengan 3 hari setelah fogging fokus pertama menunjukkan beda rata-rata $\mathrm{CI}=15,73529$ dengan $\mathrm{p}=0,006$ $(\mathrm{p}<0,05)$ hasil tersebut signifikan, artinya ada beda densitas larva sebelum fogging pertama dengan 3 hari setelah fogging pertama. Container Index (CI) sebelum dilakukan fogging fokus pertama sangat tinggi jika dibandingkan dengan Container Index 3 hari setelah fogging fokus pertama, berarti fogging fokus pertama berhasil memberikan efek berupa penurunan densitas larva.

b. Sebelum Fogging fokus pertama dengan 3 hari Setelah Fogging fokus kedua.

Hasil analisis statistik antara sebelum fogging fokus pertama dengan 3 hari setelah fogging fokus kedua menunjukkan beda ratarata $\mathrm{CI}=14,26471$ dengan $\mathrm{p}=0,012$ 
$(\mathrm{p}<0,05)$, artinya ada beda densitas larva sebelum fogging pertama dengan 3 hari setelah fogging kedua.

Fogging fokus secara teoritis dilakukan dua kali, fogging pertama dilakukan untuk membunuh nyamuk dewasa, fogging kedua dilaksanakan 7 hari setelah fogging pertama. Hal ini dimaksudkan agar jentik-jentik nyamuk sebelum fogging pertama sudah menjadi nyamuk dewasa maka, setelah 7 hari jentik-jentik tersebut telah menjadi nyamuk dewasa karna siklus perkembangbiakan dari jentik ke nyamuk dewasa adalah kurang lebih 7 hari. Dengan demikian setelah fogging kedua tidak ada lagi nyamuk dewasa yang bertelur dan menjadi jentik. Pada saat 3 hari setelah fogging fokus kedua masih terdapat jentik dengan rata-rata $\mathrm{CI}=3,9216$. Seharusnya setelah fogging fokus kedua tidak ada lagi jentik yang tersisa.

c. Sebelum Fogging fokus pertama dengan 10 hari Setelah Fogging fokus kedua.

Hasil analisis statistik antara sebelum fogging fokus pertama dengan 10 hari setelah fogging fokus kedua menunjukkan beda ratarata $\mathrm{CI}=-2.15686$ dengan $\mathrm{p}=0,701 \quad(\mathrm{p}>0,05)$, artinya tidak ada beda densitas larva sebelum fogging pertama dengan 10 hari setelah fogging kedua.

Hasil tersebut menunjukkan bahwa nyamuk masih ada bahkan CI 10 hari setelah fogging fokus kedua justru lebih banyak jika dibandingkan dengan CI sebelum dilakukan fogging fokus. Hal ini dapat di simpulkan pertama, diasumsikan bahwa nyamuk dewasa tidak mati semua ketika fogging fokus pertama maupun fogging fokus yang kedua. Buktinya masih ada nyamuk dewasa yang bertelur pada saat 10 hari setelah fogging fokus bahkan 10 hari setelah fogging fokus kedua nyamuk bertelur lebih banyak jika dibandingkan dengan sebelum dilakukan fogging fokus pertama.

Kemungkinan yang kedua bahwa telur yang masih ada saat sebelum fogging fokus pertama atau 3 hari setelah fogging fokus pertama belum menetas semua ketika dilakukan fogging fokus kedua. Hal tersebut dapat diasumsikan bahwa tidak semua telur menetas dalam waktu yang sama.

Kemungkinan yang ketiga adalah dari 2 hal di atas terjadi secara bersama-sama, yaitu bahwa tidak semua nyamuk dewasa mati saat fogging fokus pertama maupun fogging fokus yang kedua, dan tidak semua telur menetas dalam waktu yang sama. Jika kemungkinan ini terjadi, berarti 10 hari setelah fogging yang kedua perlu di lakukan fogging lagi karena 2 kali fogging saja tidak cukup untuk menurunkan densitas larva. Akan tetapi, hal ini dapat mengakibatkan terjadinya resistensi terhadap nyamuk.

d. Sebelum Fogging fokus pertama dengan 17 hari Setelah Fogging fokus kedua.

Hasil analisis statistik antara sebelum fogging fokus pertama dengan 17 hari setelah fogging fokus kedua menunjukkan beda ratarata $\mathrm{CI}=17.20588$ dengan $\mathrm{p}=0,003(\mathrm{p}<0,05)$, artinya ada beda densitas larva sebelum fogging pertama dengan 10 hari setelah fogging kedua.

17 hari setelah fogging fokus kedua terjadi penurunan secara drastis jika dibandingkan dengan sebelum fogging fokus pertama. Hal tersebut dapat terjadi karena adanya Pemberantasan Sarang Nyamuk (PSN) saat sehari sebelum pengamatan. Hal tersebut membuktikan bahwa kegiatan PSN yang dilakukan lebih bagus untuk menurunkan densitas larva karena PSN memberikan dampak secara langsung dalam menurunkan densitas larva jika dibandingkan dengan fogging. Oleh karena itu, sebaiknya kegiatan PSN lebih sering dilakukan secara berkala oleh masyarakat Desa Sidamulih baik secara mandiri di masing-masing rumah maupun secara gotong royong untuk menekan pertumbuhan nyamuk.

\section{SIMPULAN}

Hasil penelitian dianalisis dengan menggunakan uji anova one way. Hasil uji beda Container Index (CI) setelah pelaksanaan fogging fokus nilai $\mathrm{p}$ (sig) $0,000<0,05$ berarti Ho ditolak artinya ada perbedaan antara densitas larva sebelum dan setelah dilakukan fogging fokus. Karena Ho di tolak maka 
uji lanjut LSD diteruskan, hasilnya ada beda sebelum fogging fokus dengan 3 hari setelah fogging fokus pertama dan kedua, 10 hari setelah fogging fokus kedua tidak ada beda, dan setelah 17 hari fogging fokus terjadi penurunan CI secara drastis karena adanya PSN, dengan demikian fogging fokus hanya efektif untuk menekan densitas larva sampai hari ke 10 setelah fogging fokus.

\section{SARAN}

1. Bagi Dinas Kesehatan Kabupaten Banyumas Melakukan sosialisasi, pemantauan monitoring pelaksanaan PSN secara rutin, PSN secara efektif perlu mempertimbangkan hasil surveylans penyakit DBD minimal 1 bulan sebelum puncak kasus dengan siklus 1 minggu sekali, Fogging fokus hanya dilaksanakan secara selektif.

2. Bagi Masyarakat

Meningkatkan partisipasi untuk melakukan Pemberantasan Sarang Nyamuk (PSN) dengan bimbingan dari Dinas Kesehatan.

3. Bagi Peneliti lain

Melakukan uji resistensi terhadap nyamuk dewasa terhadap pestisida yang digunakan saat fogging dengan uji bio essay atau transovari, perlu ada penelitian tentang hubungan antara densitas jentik dengan kasus demam berdarah berdasarkan data surveylans penyakit DBD.

\section{DAFTAR PUSTAKA}

Arcole Margatan, 1996, Mewaspadai Demam Berdarah dan Berbagai Macam Demam Lainnya, Solo: CV Aneka

Aris Santjaka, 2011, Statistik untuk Penelitian Kesehatan 1, Yogyakarta: Nuha Medika.

Aris Santjaka, 2013, Malaria Model Pendekatan Kausalitas, Yogyakarta: Nuha Medika.

Aris Santjaka, 2015, Aplikasi SPSS Untuk Analisis Data Penelitian Kesehatan, Yogyakarta: Nuha Medika.

Ayu Yulistyawati, 2011, Penentuan Status Resistensi Nyamuk Aedes aegypti terhadap Malathion Pada Daerah Endemis Dan Non Endemis Di KotaSemarang, Skripsi, Semarang, Universitas Muhammadiyah Semarang.

Departemen Kesehatan R.I. Direktorat Jenderal Pengendalian Penyakit dan Penyehatan Lingkungan
(DIT.JEN.PP\&PL), 2007, Ekologi dan Aspek Perilaku Vektor, Jakarta: DIT.JEN.PP \& PL

Departemen Kesehatan R.I. Direktorat Jenderal Pengendalian Penyakit dan Penyehatan Lingkungan (DIT.JEN.PP\&PL), 2007, Survai Entomologi Demam Berdarah Dengue, Jakarta: DIT.JEN.PP \& PL

Departemen Kesehatan R.I. Direktorat Pemberantasan Penyakit Bersumber Binatang (DIT. P2B2), DIT.JEN PPM \& PL, 1985, Bagaimana Mencegah Demam Berdarah, Jakarta: DIT. P2B2, DIT.JEN PPM \& PL.

Dian Fergianto, 2014, Komparasi Daya Tahan Larva Aedes aegypti Pada Beberapa Kadar BOD Tahun 2014, Karya Tulis Ilmiah, Purwokerto: Kementrian Kesehatan RI Politeknik Kesehatan Semarang Jurusan Kesehatan Lingkungan Purwokerto.

Hani Arianti, 2012, Perbedaan Resistensi Nyamuk Aedes aegypti Terhadap Malathion Bersarkan Frekuensi Fogging (Studi Kota Semarang) Tahun 2012, Thesis, Semarang: Universitas Muhammadiyah Semarang.

Hendrawan Nadesul, 1998, 100 Pertanyaan Jawaban Demam Berdarah, Jakarta: Penebar Swadaya.

( , 2007, Cara Mudah Mengalahkan Demam Berdarah, Jakarta: PT Kompas Media Nusantara.

Hoedojo, 1993, Vektor Demam Berdarah Dengue dan Upaya Penanggulangannya,

http://digilib.esaunggul.ac.id/public/UEUUndergraduate-735-bab\%20II.pdf (diakses pada 25 November 2015 pukul 08.51 WIB)

http://dinkes.ntbprov.go.id/sistem/datadinkes/uploads/2013/10/RPJPK-2005-2025.pdf (diakses pada 25 November 2015 pukul 10.30 WIB)

http://download.portalgaruda.org/article.php? article $=282$ $187 \& \mathrm{val}=4899 \&$ title $=$ Maya $\% 20$ Index $\% 20$ Aedes $\% 2$ 0spp.\%20di\%20Kelurahan\%20Kutabanjarnegara\%2 0Kecamatan\%20Banjarnegara\%20Kabupaten\%20B anjarnegara (diakses pada 26 Februari 2016 pukul $05.40 \mathrm{WIB}$ )

Lila Kesuma Hairini, 2009, Gambaran Epidemiologi Demam Berdarah Dengue (DBD) dan FaktorFaktor yang Mempengaruhi Angka Insidennya di Wilayah Kecamatan Cimanggis Kota Depok Tahun 2005-2008, Skripsi, Depok: Fakultas Kesehatan Masyarakat Universitas Indonesia.

Prastiwi Fajar Isnaeni, 2013, Studi Pengendalian Vektor Demam Berdarah Dengue (DBD) di Wilayah Perimeter dan Buffer Pelabuhan Tanhung Intan 
Kantor Kesehatan Pelabuhan (KKP) Kelas II Cilacap Tahun 2013, Karya Tulis Ilmiah, Purwokerto: Kementrian Kesehatan RI Politeknik

Kesehatan Semarang Jurusan Kesehatan Lingkungan Purwokerto.

Ratna Pramurditya, 2014, Deskripsi Pelaksanaan Pemberantasan Sarang Nyamuk (PSN) Demam Berdarah Dengue (DBD) di Kelurahan Karangpucung Kecamatan Purwokerto selatan Kabupaten Banyumas Tahun 2014, Karya Tulis Ilmiah, Purwokerto: Kementrian Kesehatan RI Politeknik Kesehatan Semarang Jurusan Kesehatan Lingkungan Purwokerto.

Santoso, Ludfi, 1997, Pengantar Entomologi Kesehatan Masyarakat, Semarang: Fakultas Kesehatan Masyarakat.

Soedarto, 2009, Penyakit Menular di Indonesia, Jakarta: CV Sagung Seto

Soeroso T, Umar IA, 2002, Epidemiologi dan Penanggulangan Penyakit Demam Berdarah Dengue (DBD) di Indonesia Saai Ini. Dikutip dari Demam Berdarah Dengue. Naskah Lengkap Pelatihan bagi Dokter Spesialis Anak dan Dokter Spesialis Penyakit Dalam, dalam Tatalaksanakan Kasus DBD. Penyunting: Sri Rejeki H Hadinegoro dan Hindra Irawan Satari, Jakarta: Balai Penerbit FKUI.

Soegeng Soegijanto, 2006, Demam Berdarah Dengue Edisi 2, Surabaya: Airlangga University Press.

Sucipto, C.D. 2011. Vektor Penyakit Tropis. Yogyakarta: Goysen Publishing.

Sunaryo, Novi Pramesti, 2012, Surveylans Aedes aegypti di Daerah Endemis Demam Berdarah Dengue.

Artikel Penelitian, Balai Penelitian dan Pengembangan Pengendalian Penyakit Bersumber Binatang Banjaregara.

Thomas Suroso, 1986, Demam Berdarah Dengue Epidemiologi dan Pemberantasan di Indonesia,
Jakarta: Departemen Kesehatan R.I. Direktorat Jenderal PPM \& PLP.

Tri Wahyuni Sukesi, 2012, Monitoring Populasi Nyamuk Aedes aegypti Vektor Penyakit Demam Berdarah Dengue Di Kelurahan Gedongkiwo Kecamatan Mantrijeron Kota Yogyakarta, Skripsi, Fakultas Kesehatan Masyarakat Universitas Ahmad Dahlan.

Umar Fahmi Achmadi, 2012, Manajemen Penyakit Berbasis Wilayah, Jakarta, Rajawali Pers.

World Health Organization, 1999, Demam Berdarah Dengue; Diagnosis, Pengobatan, Pencegahan dan Pengendalian/ organisasi Kesehatan Dunia (WHO) : Alih Bahasa, Monika Ester; Editor edisi bahasa Indonesia, yasmin Asih, Ed 2, Jakarta: EGC.

_), 2004, Pencegahan \& Pengendalian Dengue \& Demam Berdarah Dengue. Jakarta: EGC.

(__ ), 2005, Pencegahan \& Pengendalian Dengue dan Demam Berdarah Dengue, Panduan Lengkap. Alih Bahasa: Palupi Widyastuti. Editor Bahasa Indonesia: Salmiyatun. Cetakan I, Jakarta: Penerbit Buku Kedokteran EGC, Hal 58-77.

(__ ), comprehensive guidelines for prevention and control of dengue and dengue haemorrhagic fever. revised and expanded edition, 2011, SEARO Thecnical Publication: India.

Zulkarnaini, Y.I. Siregar, and Dameria, Hubungan Kondisi Sanitasi Lingkungan Rumah Tangga dengan Keberadaan Jentik Vektor Dengue di Daerah Rawan Demam Berdarah Dengue di Kota Dumai Tahun 2008. Journal of Environmental Science, 2009. 2(3). 